DOI 10.22363/2313-2329-2019-27-2-303-312

UDC 331.101.6:338.2

\title{
Labor performance as one of the elements of personnel control and management in hotels in Syria
}

\section{Morhaf Farhan Alhammoud ${ }^{1}$, Alexander M. Zobov', Hassan Almyshrqi²}

\author{
${ }^{1}$ Peoples' Friendship University of Russia (RUDN University) \\ 6 Miklukho-Maklaya St., Moscow, 117198, Russian Federation \\ ${ }^{2}$ Al-Baath University \\ PO Box 77, Homs, Syrian Arab Republic
}

\begin{abstract}
Increased productivity is one of the least studied and challenging aspects of hotel and restaurant business management. The requirement to ensure productivity growth in order to survive and sustain business, including in Syria's resurgent hospitality industry, is becoming increasingly important for managers. The active work of hotel managers in motivating and controlling staff in hotels should be a relevant and popular element in the development of a modern entrepreneurial culture, and better service. This article discusses what service productivity means, especially in the hospitality industry. This is confirmed by a study of the degree of compliance of the respondent hotels, which have become the object of the study, and labor productivity indicators in order to find a suitable standard of measurement and management system for the hotel industry in Syria. The article also provides an overview of the latest trends in the hotel business of Syria and a detailed analysis of the current tourism situation in Syria, including the study of the productive capacity of the labor force in the field of tourism and hotel in Syria on the basis of age, gender and educational level of workers in this field. This study has an important impact in determining how to increase production capacity in the sector of tourism and hotel in Syria.
\end{abstract}

Keywords: labor productivity; tourism; measurement; standards; entrepreneurial culture; efficiency; hotel business; Syria

\section{Introduction}

Increasing productivity and developing labor capacity to deliver the best services are the most important entrepreneurship tools in the hotel industry. Productivity in hotel and restaurant operations is measured on the money spent, and not on the money earned in business management. The two main sources of spending are food and labor costs. When minimizing costs to reduce overall costs, labor costs should also be taken into account. There were several methods used to calculate restaurant performance and to control costs, knowing that this particular gesture was necessary for the success or failure of the institution. Some of them are the use 
of customer invoices or receipts that indicate the number of customers waiter waited per hour; daily analysis of the total working time used by each customer who is served through the payroll; measuring the remaining food each day to indicate an increase in price or an increase in serving size; taking into account the cost of food for each customer once in a while to check the profitability and accuracy of the order; and check tickets to find out how add-on sales are doing. The above methods explain only the side of the point of view of the restaurateur to measure performance; nonetheless, customer perspective is another thing. The relationship between quantity and output and the amount of input used to generate this result is called performance (Hovenga, 2010).

Performance is used as a measure of the efficiency of using resources to achieve the goal of organizations. However, the manual function does not end with the result of production, as well as the measurement of output value added management. It represents the wealth created by the production process or the provision of services. Value added measures the difference between sales and the cost of materials and services incurred to generate sales. The hospitality industry is described as the fastest growing sector with the creation of the best jobs sector. It also has a reputation for poor working conditions due to a number of factors. These factors are the low density of trade unions, work characterized by low wages and low qualifications of requirements, shifts and night work (Bondarenko, 2006.).

Thus, this study focuses on the work of various hotels in various Syrian cities and the study of problems that hinder the effectiveness of hotel work in Syria as a whole.

\section{Theoretical basis for labor productivity}

A review of relevant literature provided a solid basis for these studies. The structure that was guided by the research activities in this article is based on the official theory, according to which it was developed using an established, consistent explanation of certain types of phenomena and attitudes (Dracheva et al., 2009).

A well-known Russian hotel business specialist A.D. Chudnovsky describes a model of feedback of production work of employees in the hotel business. And the mechanism for measuring their performance and, consequently, the effective work of the hotel in its different sections, this model is reflected in Figure 1.

Thus, in order to achieve high hotel performance, it is necessary to measure the production labor of workers in this sector and solve the barriers and problems that they face in their work, hence increasing their productivity to provide the best services to the clients of these enterprises.

And to understand the purpose of the study, the researcher used the System Theory, which is an interdisciplinary field of science and the study of the nature of complex systems in nature, society and science. More specifically, it is a structure with which you can analyze and/or describe any group of objects that work in concert to produce some result.

An IPO model was used in this study. The Input - Process - Output Model, also known as the IPO Model, is a functional model and conceptual diagram of a common system. These conceptual data models take a more abstract perspective by identifying the main things, of which the things you have to deal with are just examples (Chudnovsky, 2003). The model was used because it will clearly define 
the directions of the fundamental conclusions of the study. Figure 1, shows a schematic diagram of the variables used in the study. Contribution is what influences change in organizations.

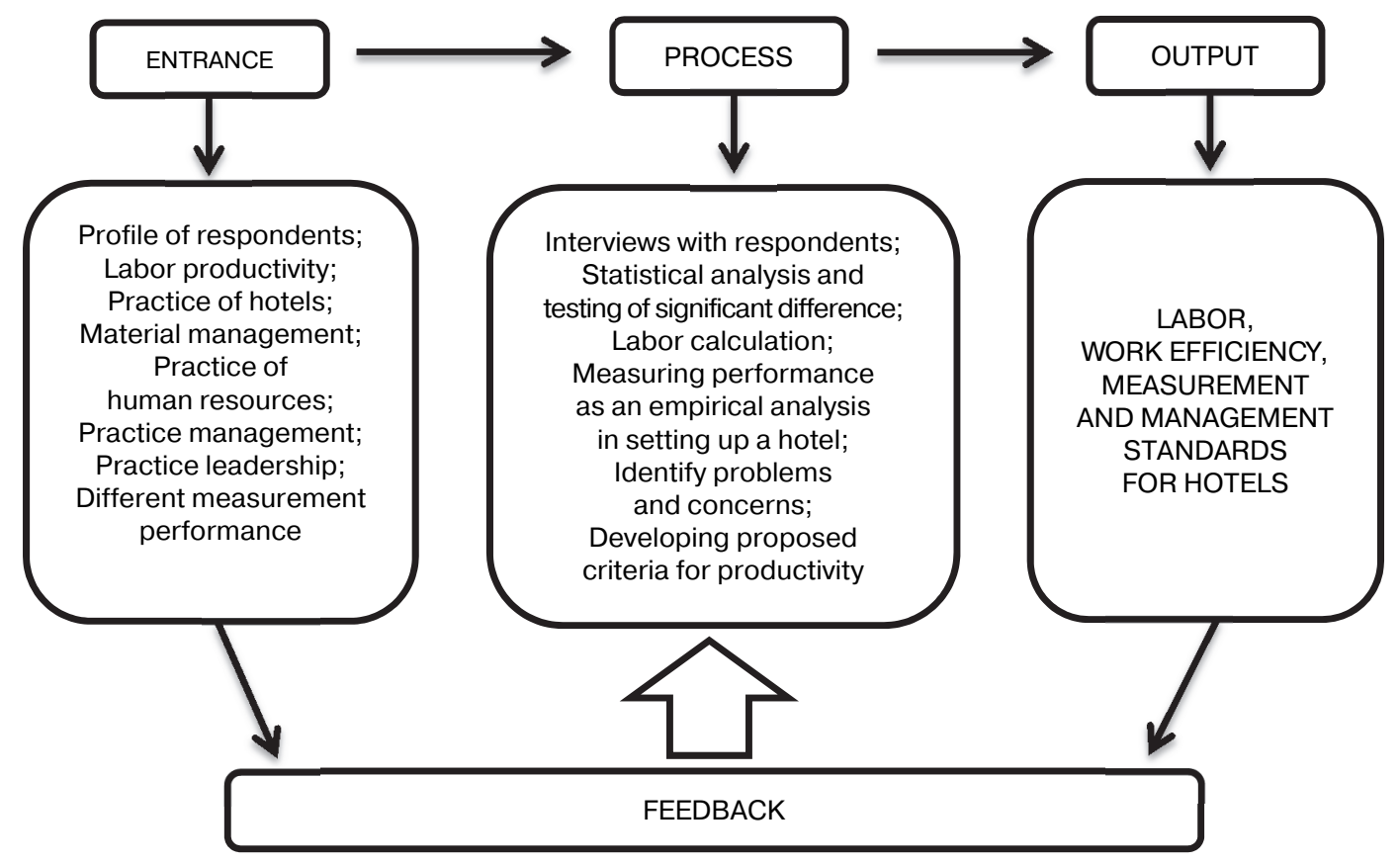

Figure 1. Research paradigm

Source: Chudnovsky A.D. Management in tourism and hotel industry: a training manual. $2^{\text {nd }}$ edition. Moscow: KNORUS Publ., 2006. 160 p.

In this way successful practice to identify elements that can make more discrepancies in one or another part of the model, modeling of business models, how the infrastructure is built, how far the organization will use unmanaged as input. Inputs consisted of a hotel and restaurant profile, a profile of managers, a profile of employees, best practices in a hotel, labor costs, labor, practicality of hotel performance, total number of employees, staff time, income of a hotel, material management practice, personnel management practice, and leadership management practices. Inputs were processed by comparing hotel productivity practices, proven labor efficiency, using participating hotels versus better labor productivity and indicators at Cornell University, evaluating the degree of compliance of labor practice productivity, checking significant differences, measuring labor productivity - empirical analysis identify problems and develop proposed criteria for performance framework (Saak, Yakimenko, 2012).

\section{Methods}

The researcher used a random sample, since the target respondents met certain practical criteria, such as accessibility, geographical proximity, and accessibility at a certain point in time or their desire. The method of statistical comparisons (correlation analysis) was used on the basis of systematization of actual factual material and publications on the Syrian hotel business. As sources of material were also used studies to identify factors that affect labor productivity in various hotels in Syria. 


\section{Results}

Syria is one of the most important tourist destinations in the Middle East and in the world, because it has all the elements of tourism, as where Syria has the oldest archaeological, tourist and religious monuments in the world, the oldest castles, streets and churches in the world - picturesque the nature of the sea and deserts, mountains and rivers, as well as an important strategic location of the Middle East - this is the point of contact between Asia and Europe and many other features. Syria has become a major event in the field of tourism and hotel business, especially between 2007-2010. The number of tourists arriving in Syria reached about 8.5 million tourists in 2010 , which is equivalent to $40 \%$ of the population of Syria. However, the period between (2011-2018) was a significant decline in the contribution of the tourism sector to gross domestic product (GDP) and employment due to the ongoing war in Syria.

The period of the war greatly influenced the number of tourists coming to Syria, especially in 2011-2016, where there was the most declines in the number of tourists (Figure 2).

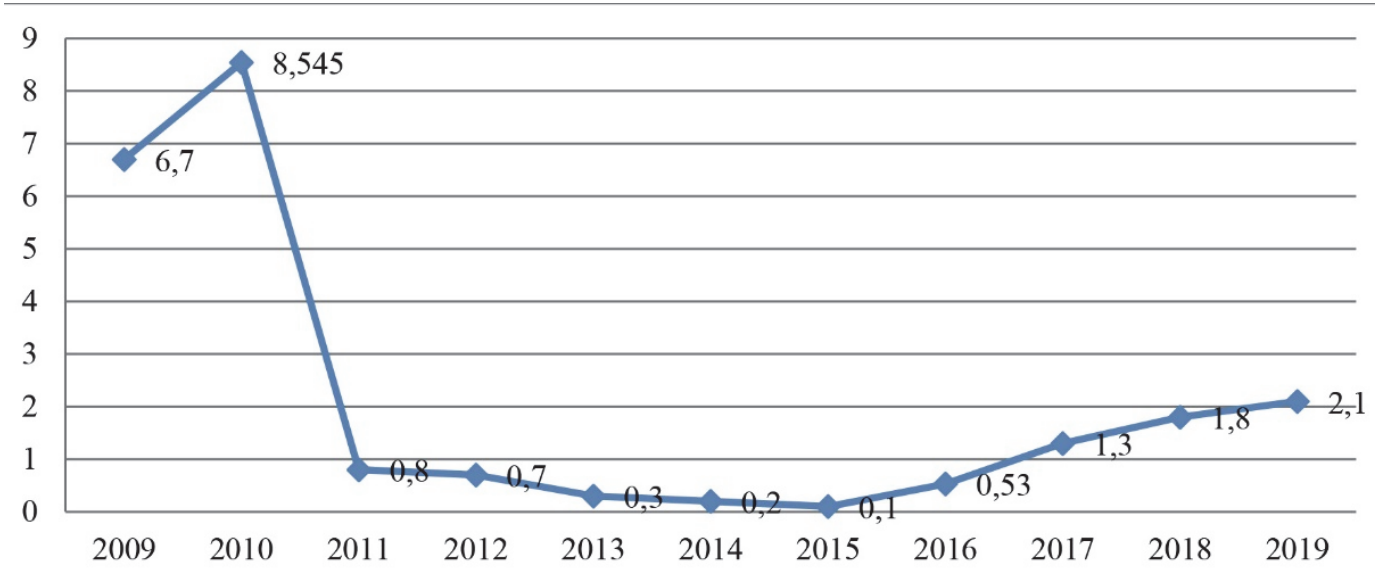

Figure 2. The forecast number of tourists coming to Syria between 2009-2019 (million tourists)

Source: Compiled by the authors on the basis of: Forecast of the number of tourists coming to Syria between 2009-2019 (million tourists). URL: https://en.wikipedia.org/wiki/Tourism_in_Syria\#cite_note-12; https://riafan.ru/1121116-siriya-sar-nadeetsya-uvelichit-chislo-turistov-do-dvukh-millionov-v-2019-godu; https://muraselo0n.com/ (accessed: 09.12.2018).

Based on the above statistics, we can conclude that the sector of tourism and hotel business has suffered greatly, especially in the period 2011-2016, and since 2017 , it began to be caught gradually and it is expected that in 2019 there will be 2 million tourists, and - this number is coherent with improved security and political and economic situations. There are a huge number of hotels in different cities of Syria, and they have done research at 41 hotels $^{1}$.

The development of tourism and hotel sector in Syria in the coming period depends greatly on improving the quality of services provided. Therefore, analyz-

${ }^{1}$ Hotel Syria. URL: https://www.tripadvisor.com/Hotels-g294010-Syria-Hotels.html (accessed: 
ing how the development of the currency is considered one of the most important current trends for the advancement of tourism and hotel sector in Syria. Among the respondents are employees and managers of participating hotels. These are 100 employees and managers in 9 hotels with a restaurant in Homs. They were selected as participants in the study thanks to their knowledge of the practice of labor productivity, and they were directly involved in the work of the hotel. The distribution of participants is shown in Table. All participants were from 9 hotels (in different Syrian cities). All questionnaires were received by the researcher and accepted as valid. Most participants come from Hotel 1, which is $15 \%$, and the smallest number of participants from the hotel $9-4 \%$. The table shows that most of the position in hotel operations was considered due to the complexity of the operation. Hotel services provide the highest level of service quality, so the workforce must have the necessary skills and knowledge to perform tasks ${ }^{2}$.

This method was used to assess labor productivity in various hotels and departments in Syria. In Table is shown a righteous analysis of hotels in different Syrian cities and different departments and the number of employees who participated in this study.

Distribution of participants

\begin{tabular}{ccccc}
\hline Hotels & Management & $\begin{array}{c}\text { Various sections } \\
\text { of the hotel }\end{array}$ & Amount & Percent \\
\hline Hotel 1 & 5 & 10 & 15 & 15 \\
Hotel 2 & 4 & 9 & 13 & 13 \\
Hotel 3 & 3 & 9 & 12 & 12 \\
Hotel 4 & 6 & 7 & 13 & 13 \\
Hotel 5 & 5 & 5 & 10 & 10 \\
Hotel 6 & 6 & 7 & 13 & 13 \\
Hotel 7 & 3 & 7 & 10 & 10 \\
Hotel 8 & 6 & 5 & 11 & 11 \\
Hotel 9 & 2 & 2 & 4 & 4 \\
Total participants & 41 & 59 & 100 & 100 \\
\hline
\end{tabular}

Source: compiled by the authors.

Thus, this division for participants in different Syrian hotels helps us to understand in which department of staff work efficiency and adequate in different hotels and to identify shortcomings in hotels and increase the efficiency and effectiveness of hotels in various Syrian cities.

Figure 3 shows that $64 \%$ of respondents are between the ages of 20 and 28 years old, $24 \%$ of respondents are in the range of 31 to 39 years old, and $6 \%$ of respondents are between 18 and 19 years old. Many of the respondents have just graduated from college and are at the elementary level. Basically, the trend of college graduates is to seek employment immediately after graduation and live for at least three years as an investment in their career growth.

\footnotetext{
${ }^{2}$ Hotel business - hospitality industry. URL: http://www.new-hotel.ru/site/bild/classification/ world-systems/ (accessed: 21.12.2018).
} 


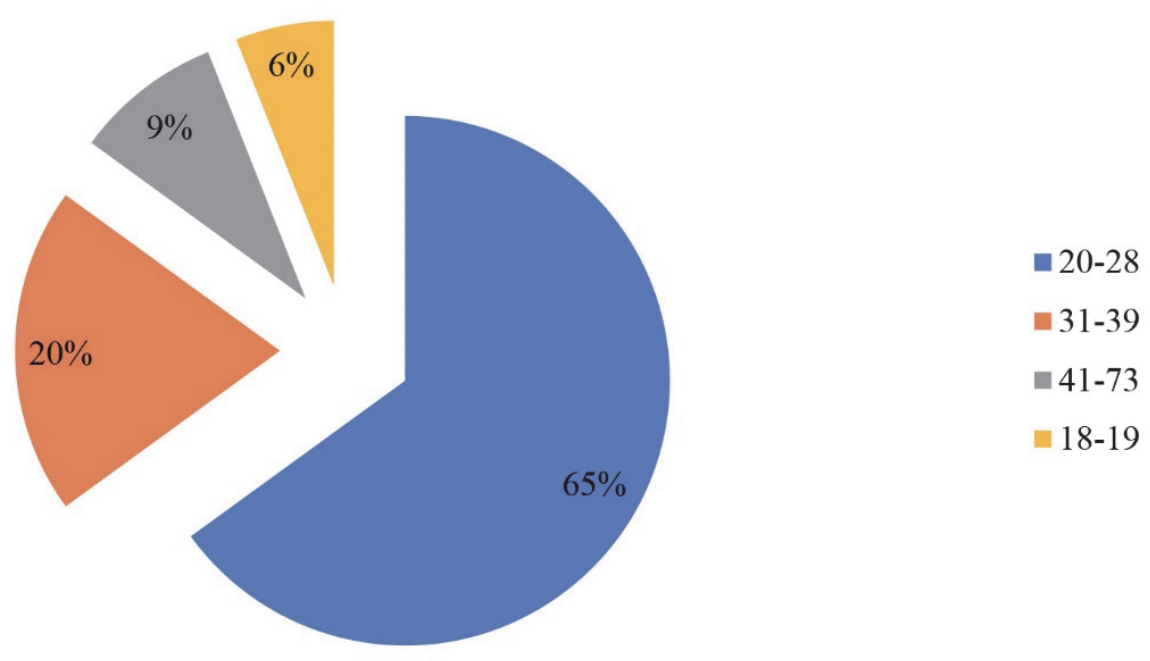

Figure 3. Age of respondents

Source: Compiled by the authors.

Thus, we can conclude that the majority of workers in the hotel business in Syria and the age of between 20-28 years. But, unfortunately, during the war, the hotel sector lost most of this age group, some of which left and some were forced to work in other sectors. Therefore, it is necessary to work to improve the security and economic situation and, thus, to achieve stability and prosperity in the hotel sector in particular and the economy in general in Syria.

Figure 4 shows that $47 \%$ of respondents are women, and $53 \%$ of them are men. The figure shows evidence that the hospitality industry requires an attractive personality to attract guests. This may be one of the main factors that lead to gender segregation in access to economic opportunities among entrepreneurs and employees: gender differences in time (mainly due to differences in care responsibilities), gender differences in access to production costs ${ }^{3}$.
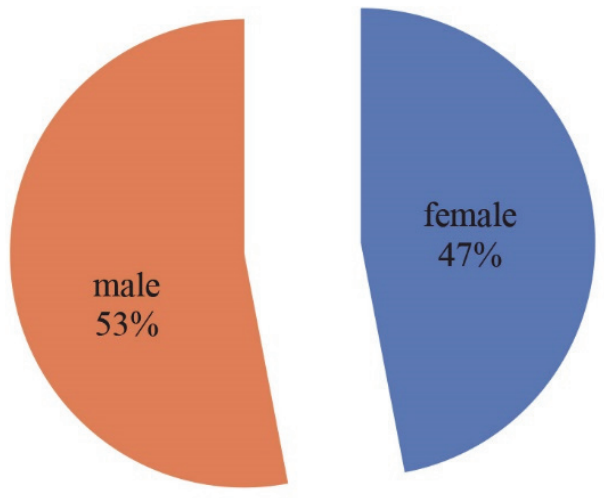

Figure 4. Gender of respondents

Source: Compiled by the authors.

${ }^{3}$ World Tourism Organization (UNWTO) report. 2016. P. 13. URL: http://www2.unwto.org/ sites/all/files/pdf/annual_report_2016_web_0.pdf (accessed: 12.10.2018). 
In the article Women in the Hotel Business (Brownell, Walsh, 2008) it was mentioned that in hospitality organizations women - whether consumers, employees or managers - face gender-related di-lemmas that are particularly difficult and acute. Experts in the tourism and hospitality industry emphasized that the individual has a high weight during the screening process, although, of course, when candidates are hired, they always have an amazing and pleasant personality, where mostly attractive and intelligent women are on the front line (Harrison, 2003).

The hospitality industry believes that employees at the front help in branding a business. Therefore, it is very important to understand how best to motivate employees, as well as develop processes and strategies to ensure the basic delivery of outstanding service and the creation of an impressive brand. Figure 5 shows that $69 \%$ of respondents are undergraduate graduates, $26 \%$ have completed vocational training courses related to the hotel and restaurant management program, and $5 \%$ of respondents are high school graduates.

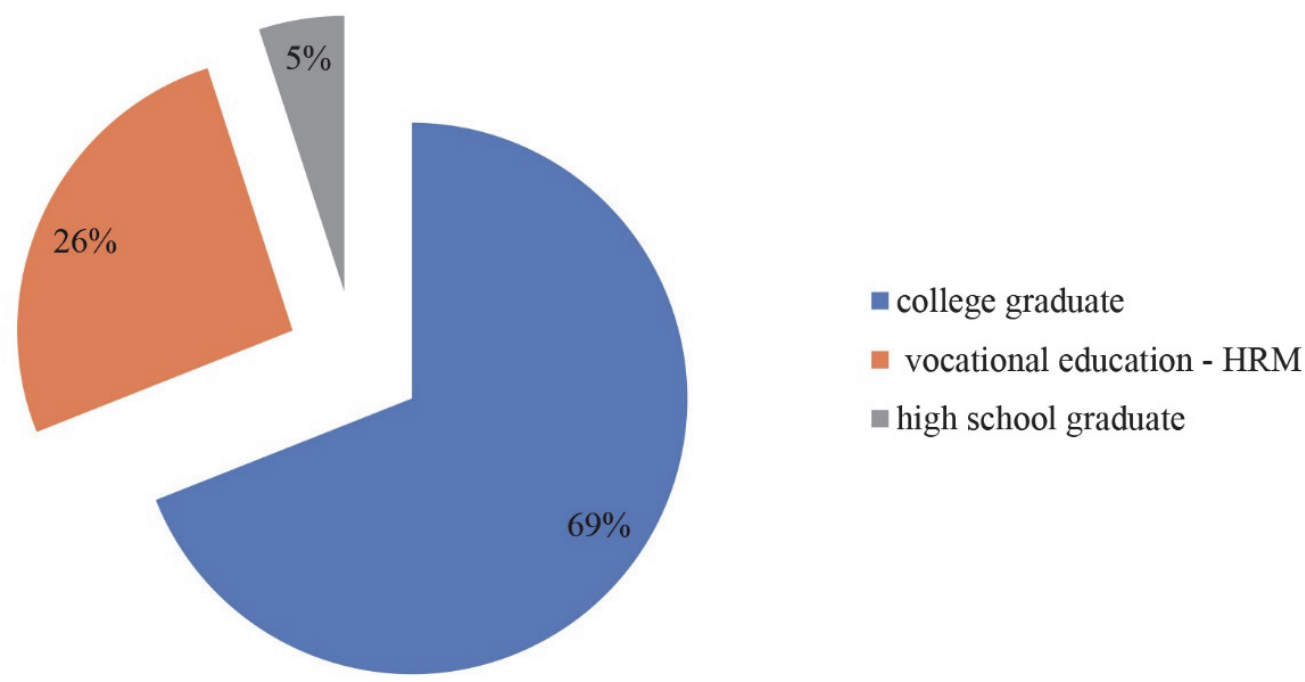

Figure 5. Achievements in education

Source: World Tourism Organization (UNWTO) report. 2016. P. 13. URL: http://www2.unwto.org/ sites/all/files/pdf/annual_report_2016_web_0.pdf (accessed: 12.10.2018).

Thus, a study conducted in which an attempt was made to apply methods for assessing labor productivity in hotels in Syria showed that many factors, such as age of employees, their gender and level of education and culture, affect the productivity of hotel companies' employees, therefore it is necessary to work on developping these aspects especially after the end of the war, which led to a significant reduction in the labor force in the hotel sector in Syria. Therefore, it is necessary to develop a strategic plan for the development of the hotel sector as a whole and to improve working conditions (for example, increasing the salaries of employees and advanced training courses that contribute to the development of the hotel sector as a whole.

The results of the study were as follows:

1) hotel profiles vary from the implementation of the practice of productivity, despite the fact that, being in the same category of hotel, that is, in a standard hotel; 
2) taking into account the indicators of the practice of increasing labor productivity in the three areas of the material, the aspects of personnel management and management, all participating hotels observed such indicators. The most observable indicators: inventory, use of the corresponding set and to show leadership on an example;

3) the results of testing hypotheses show that there is no significant difference between the ratings of participants on the degree of compliance with the practice of labor productivity. Thus, the hypothesis is accepted questions, and the problems of the participating hotels in the practice of measuring labor productivity consist of technological progress, lack of career growth and productivity, and labor costs;

4) developing the ability of the workforce to provide the best available services is one of the most important tools for the success of the hotel industry in general, so it is necessary to provide new services and unique ways to encourage and attract tourists to visit Syria, one of the best tourist countries in the world, and opened the way for the development of tourism research and labor in the future in Syria.

\section{Conclusion}

Based on the results of this study, the following conclusions were made.

1. It is concluded that the measurement of labor productivity in hotel indicators and it is important to monitor the performance of human resources, and sent to become standards, although there are others that are weak and should be even more.

2. Statistics have concluded that the group of respondents has a similar understanding of the extent of the practice of measuring productivity.

3. It is largely explained that success in the hotel business will not only rely on the number of employees, but will depend on the efficiency of each of them. Moreover, profitability ratios in proportion to each other depending on labor productivity mean that the more the hotel increases the number of its employees, the greater the cost of labor and the lower the productivity that an employee can produce.

4. In addition, despite the fact that hotel respondents practice indicators, managers and staff still face problems and challenges, such as technological advancement, lack of career paths and retention programs, lack of awareness of the impact of productivity practices and their cost and lack of bankruptcy recovery plans or dilapidated financial health. Therefore, it is necessary to formulate an individual productivity measurement and hotel management standards to help hotel owners increase their productivity while effectively addressing the company's objectives.

\section{References}

Brownell J., Walsh K. (2008) Women in hospitality. The SAGE handbook of hospitality management (pp. 107-128). Thousand Oaks, CA, Sage Publications Ltd.

Chudnovsky A.D. (2003). Turizm i gostinichnyy menedzhment [Tourism and Hotel Management]. Moscow, Tandem Publ. 447 p. (In Russ.)

Chudnovsky A.D. (2006). Menedzhment $v$ turizme $i$ gostinichnom khozyaystve [Management in tourism and hotel industry: a training manual]. $2^{\text {nd }}$ edition. Moscow, KNORUS Publ. 160 p. (In Russ.) 
Dracheva E.L., Zabaev Yu.V., Ismaev D.K. et al. (2013). Ekonomika i organizatsiya turizma: mezhdunarodnyi turizm [Economics and organization of tourism: international tour$i s m$ ]. Moscow, KNORUS Publ. 576 p. (In Russ.)

Harrison J. (2003). Strategic analysis of the hospitality industry. Cornell Hotel and Restaurant Administration Quarterly, 44(2), 139-152.

Hovenga E. (2010). Health care services, information systems \& sustainability. Studies in Health Technology and Informatics, 151, 16-29.

Saak A.E., Yakimenko M.V. (2012). Menedzhment v industrii gostepriimstva (gostinitsy i restorany): uchebnik [Management in the hospitality industry (hotels and restaurants): textbook]. Moscow. 432 p. (In Russ.)

Simpao K.J. (2018). Labour Productivity Measurement and Control Standards for Hotel. Journal of Service Science Research, 10(1), 25-76.

\title{
Article history:
}

Received: 01 April 2019

Revised: 30 April 2019

Accepted: 29 May 2019

\section{For citation:}

Alhammoud M.F., Zobov A.M., Almyshrqi H. (2019). Labor performance as one of the elements of personnel control and management in hotels in Syria. RUDN Journal of Economics, 27(2), 303-312. http://dx.doi.org/10.22363/2313-2329-2019-27-2-303-312

\section{Bio notes:}

Morhaf Farhan Alhammoud - postgraduate student, Department of Marketing, Peoples' Friendship University of Russia (RUDN University). E-mail: alkhammud@mail.ru

Alexander M. Zobov - Cand. Sc. (Econ.), Head Department of Marketing, Peoples' Friendship University of Russia (RUDN University). E-mail: a_zobov@mail.ru

Hassan Almyshrqi - Dr. of Econ., Dean of the Faculty of Tourism, Al-Baath University. E-mail: hassan1@hotmail.com

\section{Производительность труда как один из элементов контроля кадров и управления в отелях Сирии}

\author{
М.Ф. Алхаммуд ${ }^{1}$, А.М. Зобов ${ }^{1}$, Х. Алмышрки ${ }^{2}$ \\ ${ }^{1}$ Российский университет дружбы народов \\ Российская Федеращия,117198, Москва, ул. Миклухо-Маклая, 6 \\ ${ }^{2}$ Университет Аль-Баас \\ Сирийская Арабская Республика, Хомс, а/я 77
}

\begin{abstract}
Повышение производительности труда - один из самых малоизученных и сложных аспектов управления гостиницами и ресторанным бизнесом. Требование обеспечить рост производительности труда с целью выживания и поддержания бизнеса, в том числе в возрождающемся гостиничном бизнесе Сирии, становится все более важным для менеджеров. Активная деятельность гостиничных менеджеров по мотивации и контролю персонала в отелях должна быть актуальным и востребованным элементом развития
\end{abstract}


современной предпринимательской культуры и улучшения обслуживания. В статье рассмотрено значение производительности труда в сфере услуг, прежде всего в индустрии гостеприимства. Проведено исследование степени соответствия сирийских гостиниц показателям производительности труда, направленное на обнаружение подходящего стандарта измерения производительности труда и формирование продуктивной системы управления гостиничной индустрией в Сирии. Дан обзор последних тенденций в гостиничном бизнесе страны, а также подробный анализ текущей туристической ситуации, в том числе изучены производственные возможности рабочей силы в сфере туризма и гостиничного бизнеса с учетом возраста, пола и уровня образования работников этой области. Исследование может быть полезно в определении факторов увеличения производственных мощностей в секторе туризма и гостиничного бизнеса в Сирии.

Ключевые слова: производительность труда; туризм; измерение; стандарты; предпринимательская культура; эффективность; гостиничный бизнес; Сирия

\section{История статьи:}

Дата поступления в редакцию: 01 апреля 2019

Дата проверки: 30 апреля 2019

Дата принятия к печати: 29 мая 2019

\section{Для цитирования:}

Alhammoud M.F., Zobov A.M., Almyshrqi H. Labor performance as one of the elements of personnel control and management in hotels in Syria (Производительность труда как один из элементов контроля кадров и управления в отелях Сирии) // Вестник Российского университета дружбы народов. Серия: Экономика. 2019. Т. 27. № 2. C. 303-312. http://dx.doi.org/10.22363/2313-2329-2019-27-2-303-312

\section{Сведения об авторах:}

Алхаммуд Морхаф Фархан - аспирант кафедры маркетинга, Российский университет дружбы народов. E-mail: alkhammud@mail.ru

Зобов Александр Михайлович - кандидат экономических наук, заведующий кафедрой маркетинга, Российский университет дружбы народов. E-mail: a_zobov@mail.ru Алмышрки Хассан - доктор экономических наук, декан факультета туризма, Университет Аль-Баaс. E-mail: hassan1@hotmail.com 